Nicholls, L. (1945). Tropical Nutrition. London: Baillière, Tindall and Cox.

Nicholls, L. \& Nimalasuriya, A. (1939). F. Nutr. 18, 563.

Nicol, B. M. (1952). Brit. Y. Nutr. 6, 34 .

Platt, B. S. (1945). Spec. Rep. Ser. med. Res. Coun., Lond., no. 253.

Rose, W. C. (1949). Fed. Proc. 8, 546.

Sherman, H. C. (1952). Nutr. Rev. xo, 97.

Smith, E. L. (1950-I). Nutr. Abstr. Rev. 20, 795.

Soupart, P., Moore, S. \& Bigwood, E. J. (1954). J. biol. Chem. 206, 699.

Williams, C. D. (1953). Lancet, 264, 242.

Wilson, D. C. \& Widdowson, E. M. (1942). Indian med. Res. Mem. no. 34.

Woolley, D. W. (1945). F. biol. Chem. 159, 753.

Zucker, L. M. \& Zucker, T. F. (1948). Arch. Biochem. 16, I 5.

\title{
The Effect of Injections of Oestradiol Dipropionate into Immature Pullets upon the Manganese Content of the Blood Plasma and of some Tissues
}

\author{
By W. BOLTON \\ Poultry Research Centre, West Mains Road, Edinburgh 9
}

(Received I 8 October 1954)

It is well known that many of the changes taking place as a hen comes into lay can be simulated by the injection of sex hormones into immature pullets. Injections of oestrogen will evoke an increase in oviduct size and changes in the composition of the blood, although the ovaries remain quiescent. The manganese in the egg is found mainly in the yolk, with only small amounts in the albumen and shell (Romanoff \& Romanoff, 1949). It was therefore of interest to ascertain the effects of injections of oestrogen into immature pullets upon the amount of manganese in the blood plasma and in some other tissues.

Most hormone experiments are carried out by injecting equal doses of hormone at equal intervals, or by the implantation of a pellet. The gradual absorption of the latter sets free a quantity of hormone which increases rapidly at first and decreases gradually later. The daily oestrogen production of a pullet coming into lay, when plotted against time, would probably give a sigmoid curve; i.e. it would not follow either of the usual ways of administering hormones to immature pullets. The scope of the experiment was therefore extended to compare the effects of a given weight of oestrogen administered as gradually increasing doses with those obtained when the oestrogen was given as a number of equal doses.

\section{EXPERIMENTAL}

Twelve pullets, all I I weeks old and of about the same weight at the beginning of the experiment, were housed in individual all-metal cages and fed on the same mash ad lib. so that any differential effect of the oestrogen upon appetite could be measured by the resultant difference in growth rate. The oestrogen used was oestradiol dipropionate, injected in solution in arachis oil into the pectoralis muscles. The experiment 
lasted $\mathrm{I} 2$ days. Six birds received $\mathrm{I} \mathrm{mg}$ oestradiol dipropionate on each of the first I I days (control group); the other six received doses of $0,0.1,0.2,0.4,0.7,1 \cdot 0,1 \cdot 3$, $\mathrm{I} \cdot 6, \mathrm{r} \cdot 8, \mathrm{I} \cdot 9$ and $2 \cdot 0 \mathrm{mg}$ oestradiol dipropionate on these days. The doses were derived from the formula dose $=\mathrm{I} \pm \log _{10} x$, where $x$ varied between $\mathrm{I}$ and $\mathrm{ro}$; this group will be referred to as the log dose group.

On the 12th day the birds were killed by bleeding to death under nembutal anaesthesia. Coagulation of the blood was prevented by heparin. The manganese contents of nembutal and of heparin were found to be negligible. Five non-laying and seven laying birds were killed in a similar manner and gave control figures for the content of manganese.

During the dissection of the pullets the distance between the free posterior ends of the pubes (pelvic distance) and the length of the extended oviduct were measured. The quantity of fatty acid and of protein in the livers was determined by the method of McCance \& Shipp (1933); manganese was estimated by the method described previously (Bolton, 1954) and the plasma calcium by the method of Halverson \& Bergeim as described by Peters \& Van Slyke (1932).

\section{RESULTS}

In the anatomical results set out in Table I it will be noted that the final live weight of the log dose group was slightly greater than that of the control group, suggesting a greater stimulation of appetite. The tendency for the responses of the log dose group to be greater than those of the control group is evident throughout and though no single difference, with the exception of that for plasma manganese, is statistically significant, the chance of these differences all being in the same direction if the two responses were the same is significant (odds of 64 to $\mathrm{I}$ ). It is suggested that the overall effect of administering the oestradiol dipropionate in increasing doses is slightly greater than that secured by giving the same weight of hormone as a series of equal doses.

Table 1. Information about anatomical and other characteristics of hens given oestradiol dipropionate as gradually increasing doses or as equal doses

Initial weight $(\mathrm{kg})$
Final weight $(\mathrm{kg})$
Ovary weight $(\mathrm{g})$
Oviduct length $(\mathrm{mm})$
Oviduct weight $(\mathrm{g})$
Liver weight $(\mathrm{g})$
Spleen weight $(\mathrm{g})$
Distance between pubic bones $(\mathrm{mm})$
Kidney weight $(\mathrm{g})$
Plasma calcium $(\mathrm{mg} / \mathrm{I}$ oo $\mathrm{ml}$.

Unequal doses
0.80
$1 \cdot 05$
$0 \cdot 24$
384
$10 \cdot 63$
$43 \cdot 52$
$1 \cdot 12$
41
16.99
$33 \cdot 4$

Equal doses
0.80
$1 \cdot 01$
$0 \cdot 25$
374
$9 \cdot 93$
$38 \cdot 32$
$0 \cdot 98$
37
$16 \cdot 09$
$33 \cdot 0$

The quantity of manganese in the blood plasma and in the tissues is set out in Table 2. The quantity in the livers of the oestrogen-treated birds lay between those for the layers and non-layers, but the quantity in the plasma greatly exceeded both. However, it must be remembered that the ovaries of the oestrogen-treated birds were quiescent, whereas yolk material was being laid down in the ovaries of the laying hens. 
This yolk deposition would tend to remove manganese from the blood, and the higher plasma levels may therefore merely be the result of an absence of yolk deposition. This hypothesis is supported by the results for the fatty-acid contents of the livers, which were also higher than in layers.

Table 2. Manganese in plasma, liver, kidney and spleen and protein and fat in liver of hens given oestradiol dipropionate as gradually increasing doses or as equal doses

\begin{tabular}{|c|c|c|c|c|}
\hline & Non-layers & Layers & Unequal doses & Equal doses \\
\hline Plasma Mn $(\mu \mathrm{g} / \mathrm{r} 00 \mathrm{mI})$. & $\begin{array}{l}\text { None } \\
\text { detected }\end{array}$ & $6 \cdot 35$ & $34 \cdot 9$ & I $3 \cdot 8$ \\
\hline Liver Mn ( $\mu \mathrm{g})$ & $58 \cdot 4$ & $89 \cdot 3$ & $78 \cdot 3$ & $77 \cdot 3$ \\
\hline Kidney Mn $(\mu \mathrm{g})$ & $8 \cdot 2$ & $20 \cdot 5$ & $23 \cdot 1$ & $22 \cdot 6$ \\
\hline Spleen Mn $(\mu \mathrm{g})$ & 0.56 & $\begin{array}{l}\text { None } \\
\text { detected }\end{array}$ & 0.05 & 0.05 \\
\hline Liver protein (\%) & $21 \cdot 4$ & $20 \cdot 2$ & $18 \cdot 0$ & $18 \cdot 7$ \\
\hline Liver fat $(\%)$ & $4 \cdot 5 \mathrm{I}$ & 5.42 & $7 \cdot 26$ & 6.95 \\
\hline
\end{tabular}

DISCUSSION

Though the response to the oestradiol dipropionate at the level used in this experiment was probably slightly greater when the hormone substance was administered as the log dose than as the level dose, it was substantially of the same order of magnitude with both treatments. The administration of a given weight of hormone is more easily effected by giving it in a number of equal doses. It would appear that this procedure is justified when single hormone treatments are used, but in view of the synergisms and antagonisms found when more than one hormone is administered, the situation then obtaining still requires examination.

The increase in plasma manganese over that found in non-laying hens on the same diet when immature pullets were dosed with oestradiol dipropionate may be compared with similar increases reported for plasma riboflavin (Common \& Bolton, 1946) and for plasma vitellin phosphorus and plasma phospholipid phosphorus (Common, Rutledge \& Bolton, I946-8), which are all found abundantly in yolk material. These workers also found that the plasma levels could be raised above those of laying birds by treatment with oestradiol dipropionate. The effect of the oestrogen treatment on the plasma manganese was thus similar to that reported for the plasma contents of other yolk constituents. Manganese would therefore appear to be mobilized for yolk formation at about the same time as the proteins and lipids. Although plasma-lipid estimations were not carried out in this experiment, the appearance of the plasma confirmed that lipid had markedly increased.

The difference between the quantities of manganese in the kidney of laying and of non-laying hens is too small for this organ to be regarded as playing any active role in the translocation of manganese from the food to the egg, but it may act as an ultimate depot. On the other hand, the difference between amounts of manganese in the liver of laying and of non-laying hens suggests that the liver may function for manganese similarly to the way in which the skeleton functions for calcium. Common (1938) found that sufficient calcium for about six eggs was stored in the skeleton during the 
pre-laying period; the excess of manganese in the liver of the laying hen over that of the non-laying hen would provide for about three yolks.

\section{SUMMARY}

I. The effects of a given weight of oestradiol dipropionate administered to immature pullets $(a)$ as a series of equal doses (control group) and $(b)$ as a series of increasing doses (log dose group) on end-organ response and on the manganese in the blood plasma and in some tissues has been determined. The amount of manganese in similar tissues from laying and from non-laying birds was also determined.

2. Though the response to the log dose treatment was slightly greater than that of the control, both were of substantially the same order of magnitude.

3. The amount of manganese in the plasma showed after oestrogen treatment a large increase over that in the non-laying bird.

4. It is suggested that the manganese in the liver may act as mobile reserve for egg production.

\section{REFERENCES}

Bolton, W. (1954). Unpublished.

Common, R. H. (r938). F. agric. Sci. 28, 347.

Common, R. H. \& Bolton, W. (1946). Nature, Lond., r58, 95.

Common, R. H., Rutledge, W. A. \& Bolton, W. (1946-8). F. Endocrinol. 5, i 2 r.

McCance, R. A. \& Shipp, H. L. (I933). Spec. Rep. Ser. med. Res. Coun., Lond., no. I 87.

Peters, J. P. \& Van Slyke, D. D. (1932). Quantitative Clinical Chemistry, Vol. 2. Methods. London: Baillière, Tindall and Cox.

Romanoff, A. L. \& Romanoff, A. J. (1949). The Avian Egg. London: Wiley. 